появления новых лексических единиц, особенностей их распространения, употребления в различных типах дискурсов.

$$
* * *
$$

1. Ильинская Я.А. Лингвистические особенности англоязычного чата // Вестник науки и образования. Иваново: Олимп, 2020. - № 10-2 (88). - С. 62-64.

2. Смирнов Ф.О. Национально-культурные особенности электронной коммуникации на английском и русском языках: автореф. дис. канд. филол. наук: 10.02.19, Яросл. гос. пед. ун-т. им. К.Д. Ушинского - Ярославль, $2004-22$ c.

3. Халяпина Л.П. Интернет-коммуникация и обучение иностранным языкам / Л. П. Халяпина, М-во науки и образования РФ, Кемер. гос. ун-т, Каф. англ. филологии № 1, Кемерово, 2005. - 210 с.

4. Longman Dictionaries Online U.S.A. Longman Dictionary of American English 5th edition - with new collocation information and vocabulary practice [Электронный pecypc] // Longman Dictionaries online URL: http://longmandictionariesusa.com.

5. «Twitter» - социальная сеть [сайт] URL: https://twitter.com/twitter.

\title{
Бурцев В.А., Тульчинская Т.Г. \\ Работа редактора над языком и стилем местных СМИ (на материале городских и районных газет Липецкой области)
}

Елецүкий государственный университет им. И.А. Бунина

(Россия, Елеи)

doi: 10.18411/trnio-10-2021-133

\section{Аннотация}

В статье рассматриваются типичные языковые и стилистические средства, которые используются в местной прессе. Анализ проводится с целью выявления лингвометодических проблем, которые могут возникнуть перед редактором при оценке языка и стиля рукописи автора регионального издания. Обосновывается положение о существенных отличиях журналистского узуса местных СМИ от стандартов речевого поведения в центральных массмедиа. Рассматривается также нормативный аспект языка местных СМИ. Кратко описаны возможные приемы редакторской работы с текстами местных СМИ, сделан вывод о низкой эффективности региональной журналистики в плане воздействия и нормотворческой деятельности.

Ключевые слова: речевые ошибки, местные СМИ, литературное редактирование, стандартизованность языка, демократизация языка.

\section{Abstract}

The article examines the typical linguistic and stylistic means that are used in the local press. The analysis is carried out in order to identify linguistic and methodological problems that may arise before the editor when evaluating the language and style of the manuscript of the author of a regional publication. The article substantiates the position on the significant differences between the journalistic usage of local media and the standards of speech behavior in the central mass media. The normative aspect of the language of local media is also considered. The possible methods of editorial work with the texts of local media are briefly described, the conclusion is made about the low efficiency of regional journalism in terms of impact and norm-setting activities.

Keywords: speech errors, local media, literary editing, standardization of the language, democratization of the language.

Статья посвящена рассмотрению особенностей языка и стиля текстов местных печатных СМИ (районные и городские газеты) с точки зрения процесса литературного редактирования. Новизна исследования заключается в том, что оно предоставляет конкретные сведения для выработки каталога лексико-стилистических и грамматикостилистических ошибок в местной прессе, которые редактор должен уметь распознавать. 
Актуальность работы связана с необходимостью изучения того, как функционирует язык в современном профессиональном журналистском региолекте.

В качестве материала исследования использовались тексты районных и городских газет Липецкой области за период с 2017 по 2021 гг. В целом статья обобщает материалы мониторинга районных и городских газет Липецкой области который провел один из авторов статьи в рамках семинара-практикума «Язык и стиль местных СМИ» для корректоров и редакторов районных газет Липецкой области в июле 2017 г. [8].

В первой части статьи рассматривается проблема стиля районной прессы. Во второй отмечаются наиболее характерные для текстов местных СМИ речевые недочеты. Третья часть посвящена проблеме стандартизованности языка местной прессы, тому, как используются в нем клишированные обороты речи. Все это - общие проблемы языка СМИ. Нам важно было выяснить, как они проявляются в липецких газетах.

Как отмечают многие исследователи, в современных СМИ наблюдается уменьшение книжности текста и возрастание «личностного» начала. Данное явление характеризуется как «демократизация языка» [2; 6]. Проявления демократизации языка в прессе в 90-е г. XX в. и в нач. 2000-х гг. - это разговорная лексика и жаргонизация. В настоящее время актуальны уже другие источники демократизации языка публицистики - это, прежде всего, интертекстуальность, языковая игра и субъективная модальность. Как представляется, если языковой материал в газете содержит эти речевые особенности изложения, то он должен быть признан соответствующим речевому узусу массмедиа. Рассмотрим кратко, проявляется ли демократизация в районной прессе на примере использования интертекстем и субъективной модальности.

По материалам мониторинга отмечаются следующие характерные особенности в использовании интертекстем. В 85 номерах районных и городских газет Липецкой области за июнь 2017 г. была найдена только одна интертекстема: До чего дошел прогресс (об использовании новейшей техники в сельском хозяйстве). Другие случаи включения «чужих текстов» были расценены как речевые штампы (согласно признакам этого типа речевого недочета - частое использование, стертость экспрессии) или как речевые ошибки (чаще всего - в связи с немотивированной трансформацией формы и значения исходного выражения). Если брать материал газет за 2021 год, то он также свидетельствует о низкой частотности интертекстем и их использовании как штампов или немотивированных трансформов идиом:

(1) Борьба разгорелась упорная, но победила дружбба.

(2) Метод прост как Божий день.

В (1) речевой штамп победила дружба; в (2) немотивированная трансформация формы фразеологизма ясно как Божий день [11, с. 195].

По нашим наблюдениям, только в этом качестве интертекстемы функционируют в местной прессе.

Семантика и средства модальности широко описаны в литературе [1; 5]. Что касается использования средств модальности в районных газетах Липецкой области, то в качестве стилистической нормы в них преобладают лишенные субъективности, книжно-официальные формы изложения, а в некоторых случаях - откровенный канцелярит. Наиболее характерное стилистическое средство в местной прессе - это общекнижная лексика. О высокой частотности данного типа стилистических единиц можно судить по примеру (3), в котором общекнижная лексика представлена как часть тезауруса только одного текста.

(3) Домашняя птииа, исследовательские работы, экологическое воспитание, областные конкурсы, всероссийские конференции, стаж по выслуге лет, индивидуальное предпринимательство, продажи продуктов, хозяйственные товары, селяне, уплата налогов, маточное стадо, зимнее время, иммунитет, благоприятные климатические условия.

Пример (4) - собственно текстовая иллюстрация частотности общекнижных средств выражения (выделены жирным шрифтом): 
(4) Наряду с садоводством, он занимается и выращиванием овощей. На достигнутом останавливаться не собирается, планирует расиирять плоцадь, благо, возможность для этого есть.

В следующем ниже разделе показаны три «опасные» для авторов местных СМИ языковые сферы: употребление фразеологизмов, лексическая сочетаемость и связанная с нею словесная ассоциативность, грамматическая сочетаемость. В силу ограниченности объема статьи приводятся только иллюстрации, но за ними в действительности стоит очень обширный материал. Типология речевых ошибок опирается на классификации из широко известных работ [9; 10; 12]. Рассмотрим особенности употребления фразеологизмов.

(5) В рамках акции также проводятся просветительские мероприятия, чтобы напомнить, что каждый человек может сделать личный вклад в сохранение воды.

В примере (5) трансформируется форма фразеологизма внести вклад [11, с. 87]. Между тем контекстуальных оснований для ее трансформации нет. Кроме того, в целях лучшего восприятия содержания лучше использовать не многочленное сложное предложение, а более сегментированную конструкцию.

Нарушение лексической сочетаемости является одной из самых частотных ошибок среди лексических недочетов, допускаемых в местной прессе. Она обусловливается, в частности, тем, что не учитывается сочетаемость слов, определяемая их лексической семантикой или стилистической окраской.

(6) Особняком среди конкурсных испытаний значилась работа с микроскопом. С помощью этого сложного прибора участники соревнований определяли активность биологического материала, рассказывали о его устройстве и основных функциях.

Слово особняком (значилась) имеет значение «в стороне от других» и сочетается со словами находится, живет, стоит: Ср.: $B$ больнице Чагин держался особняком, дружбы, даже приятельства ни с кем не заводил (И. $\quad$ Грекова. Перелом.) [НКРЯ].

Ненужные ассоциации - это еще один тип ошибок, который характерен для местных массмедиа. Как правило, причиной этих ошибок является то, что автор не учитывает все входящие в значение слова признаки, а также те семантические свойства слова, которые могут быть обусловлены представлениями читателей о предмете или явлении действительности. Если редактор вслед за автором тоже пропускает какую-то часть значения, то это может привести к ненужным ассоциациям. Рассмотрим следующие примеры.

(7) Праздничную программу скрашивали приятная музыка и долгожданная всеми летняя погода, работал буфет.

Ошибка вытекает из того, что автор не учитывает лексическую семантику глагола скрашивать («делать менее заметным что-нибудь неприятное, отрицательное») [7, с. 725]. Получается, что праздничная программа настолько плоха, что лишь хорошая погода и закуски из буфета заставляют публику держаться неподалеку от проводимого мероприятия.

(8) Сегодня ваш день, - поприветствовал молодежь ... председатель районного Совета депутатов. - День, когда ваши мысли светль и помыслы чисты.

Ни автор, ни редактор не придали значения тому, что прочтение фразы может быть таким: «Только один день в году у молодежи мысли светлы и помыслы чисты, а в остальные дни мысли все-таки темные и помыслы грязные».

Грамматические ошибки, которые встречаются в местной прессе, чаще всего представляют собой речевые недочеты, отражающие недопустимые комбинации грамматических значений компонентов предложений. Например:

(9) Работа сразу давалась легко.

Глагол прошедшего времени несовершенного вида со значением повторяющегося действия не может сочетаться с обстоятельством, передающим значение «в тот же момент». Ср.: В тот же момент он читал лекции по русскому языку. 
(10) Надо отдать должное заместителю главы: стройный, подтянутый, он не хуже других стремился к высоким результатам, подав личный пример.

Глагол стремиться в значении «настойчиво добиваться, сильно желать чего-либо» не сочетается с наречием не хуже (других). Он сочетается с наречиями меньше или больше. Кроме того, здесь следует использовать форму деепричастия настоящего времени, а не прошедшего. Во всех таких случаях редактор должен видеть возможные варианты грамматической связанности: и те, которые определены нормами, и те, которые приемлемы в условиях данного контекста.

Особая проблема для местных СМИ - использование языковых клише. Здесь также наблюдаются многочисленные речевые недочеты. Как известно, ведущая стилевая черта публицистики - стандартизованность речи [3, с.180, 188; 4, с. 345], которая определяет использование языковых клише (газетизмов). Однако в местной прессе стандартизованность выражается в безбрежном употреблении штампов. Наиболее частотны в газетах Липецкой области такие штампы:

(11) никого не оставили равнодушными, сельские поселения, отрадно было видеть, время пролетело незаметно, задумка, за чашкой чая, праздничное действо, приглашение поучаствовать, с пониманием относится, музыкальные композиции, вокальные композиции, танцевальные композиции, дан старт, изюминка, откровенно порадовало, оценить по достоинству, умелец, виновники торжества.

Почему этот штампы? Потому что они переносятся из текста в текст, создавая «убийственное однообразие» [4, с. 183], потому что ряд выражений - канцеляризмы или профессионализмы, потому что многие из выражений утратили в «местных текстах» точное значение (композиция, действо). Приведем собственно текстовые примеры только со словом задумка.

(12) Задумка нашла отклик во многих сердиах; Хорошая задумка - провести молодёжный день спорта в преддверии праздника молодёэи. Примечательно, что в ходе смотра-конкурса руководители сельских администраций активно обсуждали увиденное, делились впечатлениями, отмечали наиболее удачные идеи и задумки. Есть у хозяев и ещё одна задумка, которую они планируют реализовать в следующем году.

В заключение важно отметить следующее: языковые и стилистические недочеты местных СМИ проявляются радикальным образом: в низкой популярности изданий. Кроме того, газеты оказываются не способными осуществлять задачи в плане воздействия на адресата. Наконец, язык тех местных газет, в которых по каким-то причинам актуализированы нестандартные способы использования общенародного языка, влечет добавочные языковые дифференциации. Если они не мотивированы, то речь журналистов в итоге оказывается средством дезориентации читателей в вопросе нормы литературного языка.

$$
* * *
$$

1. Бирюлин Л.А. Основные типы модальных значений, выделяемых в лингвистической литературе // Теория функциональной грамматики: Темпоральность. Модальность. - Ленинград, Издательство «Наука. Ленинградское отделение», 1990. - С. 67-71.

2. Казак М.Ю. Язык газеты: учеб. пособие. - Белгород: ИД «Белгород», 2012. - 120 с.

3. Кожина М. Н., Дускаева Л. Р., Салимовский В. А. Стилистика русского языка. - Москва: Флинта, Наука, 2008. $-462 \mathrm{c}$.

4. Костомаров В.Г. Русский язык на газетной полосе. - М.: Издательство МГУ, 1971. -268 с.

5. Модальность в языке и речи: новые подходы к изучению: сб. науч. тр. под ред. С.С. Ваулиной. Калининград: Изд-во РГУ им. И. Канта, 2008. - 350 с.

6. Мустайоки А. Разновидности русского языка: анализ и классификация // Вопросы языкознания. - 2013. - № 5. - C. 3-27.

7. Ожегов С.И. и Шведова Н.Ю. Толковый словарь русского языка. - 4- изд., дополненное. - М.: Азбуковник, 1999. - $944 \mathrm{c}$.

8. Пресса. Наука. Власть // Новости Липецка и Липецкой области - Безформата. - URL: http://www.lipeck.bezformata.com. 
9. Сулименко Н.Е. Стилистические ошибки и пути их устранения: Пособие для учителей. - М.-Л.: Просвещение, 1966. - 134 с.

10. Фоменко Ю. В. Типы речевых ошибок. - Новосибирск: НГПУ, 1994. - 65 с.

11. Фразеологический словарь русского литературного языка: в 2 т. / Сост. А.И. Федоров. - Новосибирск: ВО «Наука». Сибирская издательская фирма, 1995. - Т.1. - 391 с.

12. Цейтлин С.Н. Речевые ошибки и их предупреждение. - М.: Просвещение, 1982. - 128 с.

Крехтунова Е.В., Шишкова Я.А.

Репрезентация актуальных неологизмов в современном интернет-дискурсе

Пензенский государственный университет

(Россия, Пенза)

doi: 10.18411/trnio-10-2021-134

\section{Аннотация}

Статья посвящена анализу лексической системы языка, которая являясь наиболее гибкой и подвижной, непрерывно изменяется, обогащаясь новыми лексическими единицами и отражая актуальные социальные тенденции. Новые слова, появившиеся в интернет пространстве за последние несколько лет, стали объектом изучения данной статьи. Материалом послужили неологизмы, полученные в результате опроса студентов. В работе рассматривается специфика популярных неологизмов английского языка и актуализация их в повседневном общении не носителей языка. Приведены результаты опроса, а также предпринята попытка разобраться в причинах происходящих изменений.

Ключевые слова: неологизмы, интернет-дискурс, сленг, жаргон.

\section{Abstract}

The article is devoted to the analysis of the lexical system of the language, which, being the most flexible and mobile, is constantly changing, enriching itself with new lexical units and reflecting current social trends. New words that have appeared in the Internet space over the past few years have become the object of study of this article. Neologisms obtained as a result of a survey of students was the material of research. The paper examines the specifics of popular neologisms of the English language and their actualization in everyday communication of nonnative speakers. The results of the survey are presented, and an attempt is made to understand the reasons for the changes.

Keywords: neologisms, Internet discourse, slang, jargon.

Сегодня современное общество сложно представить без интернета. Социальные сети, мессенджеры, цифровые платформы стали неотъемлемой частью жизни современного человека. Все это оказало невероятное влияние на сам язык, в частности на его лексическую составляющую. И как любая система, которая развивается достаточно быстро, современный язык стремительно приспосабливается к постоянно меняющимся условиям. Сегодня человека окружает большое количество заимствований, сокращений и неологизмов, происходит замена значений старых привычных слов, наращение новых смыслов, появление мейнстримов. Интернет становится первопричиной таких изменений, и неким их «архиватором», посредством которого мы можем проследить за всеми этими процессами.

Для начала стоит обратиться к определению неологизма. Неологизм - новое слово или выражение, а также новое значение старого слова [6, 1999: 36].

Новые слова и выражения (неологизмы) создаются для обозначения новых понятий, появляющихся в той или иной культуре. Они номинируют политические и социальные явления, называют реалии моды (одежду, прически, обувь и пр.), продукты питания. При этом, как правило, старые слова приобретают новые значения или новые слова заимствуются из языка-донора. Интересно, что новые слова зачастую образуются из уже существующего в языке лексического и словообразовательного материала и в соответствии со способами, продуктивными в языке [3, с.111]. 